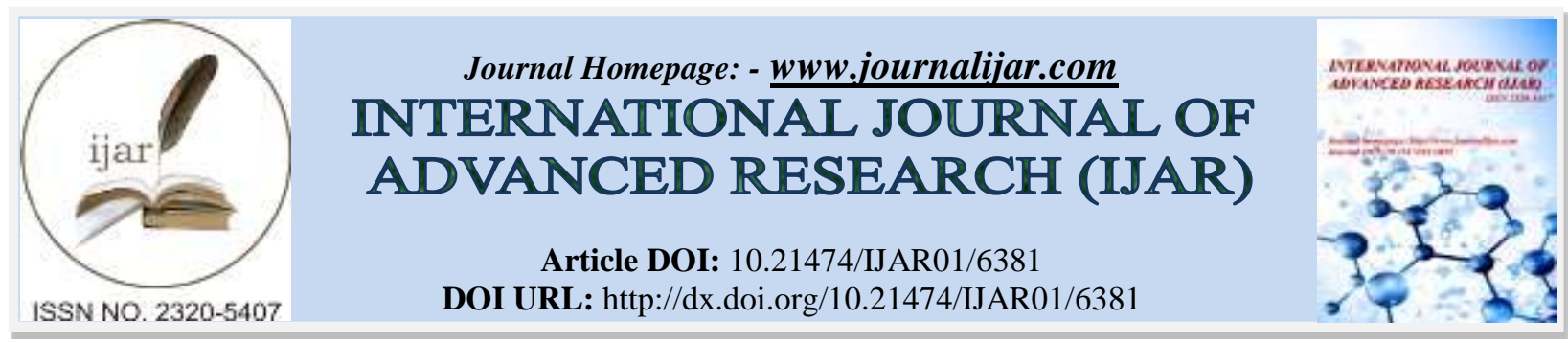

RESEARCH ARTICLE

\title{
APPROXIMATION VOGELS EFFECTIVENESS METHOD (VAM) MINIMIZE COST OF TRANSPORTATION.
}

Valdo Pasaribu, Sutarman and Saib Suwilo.

Faculty of Mathematics and Natural Sciences, Universitas Sumatera Utara.

\section{Manuscript Info}

Manuscript History

Received: 22 November 2017

Final Accepted: 24 December 2017

Published: January 2018

\begin{abstract}
This research aims to identify and excellence VAM methods to minimize transportation costs. The data used in this research is secondary data. Based on the results of the discussion that has been done in this study, in the case of UD. Berdikari Tani distribution acquired its initial solution is 5.70312 million, - through 6 stages using the VAM method, while the method of NWC obtained initial solution of 5.71624 million, - through six stages as well. Furthermore, from the results of testing the optimum solution MODI method of both methods is the method of VAM and VAM NWC obtained that the method is better than the NWC because the testing table VAM optimum solution immediately obtained the optimum solution that is equal to 5.70312 million while at the beginning of the solution table NWC testing methods MODI found negative index numbers so that the table is called not optimal. In the case of the Southern Area Semen Bosowa distribution obtained initial solution of 27.875 million, - through seven stages using the VAM method, while the NWC method to get the initial solution of 31.875 million, - through seven stages. Furthermore, testing optimum solution methods VAM MODI of the initial solution obtained was 27.75 million. This results in an optimum value of transport costs as compared with the optimum solution testing method NWC MODI of the initial solution that is equal to 30.875 million.
\end{abstract}

Copy Right, IJAR, 2018,. All rights reserved.

\section{Introduction:-}

Many operations research models that have been developed related to mathematics. Linear programming is one of the tools used to solve the optimization problem of a linear model with the limitations provided. Linear program already used in industry, transport, trade, economic and other fields. One special kind of linear programming is the problem of transportation.

The transportation problem is one of the issues analyzed in the early history of the linear program. Common Problems arise when the goods are available in several sources such as warehouses or factories, should be sent to various destinations such as retail outlets or distribution center, next is to determine the delivery schedule that minimizes transportation costs. It is assumed that the cost of shipping goods from source to destination is directly proportional to the amount of goods shipped. 
Transportation activities can be regarded as supporting the activities of the company in competition, because with the application of transport then a company can distribute products to consumers appropriately and also can determine their distribution costs of the most minimal so as to create efficiencies in the company's distribution costs (Thie., 2008).

The problem of transport has several characteristics, among others:

1. There are a number of sources and a number of specific objectives.

2. The number or quantity of goods distributed from any source and that is required by each specific goal is.

3. The number or quantity of goods sent from any source to a destination in accordance with the request or resource capacity.

4. The cost of transportation from a source to a destination is specified (Zulfikarizah., 2004).

The first step to resolve the transportation problem is to determine the initial feasible solution. There are four methods to determine the solution feasible beginning:

1. Method Corner Northwest(Northwest Corner)

2. Method of Least Cost (Least Cost)

3. Method Approach Vogel(Vogels Approximation Method/NAM)

4. method of Russell's Approximation Method (RAM)

After getting the solution feasible beginning we then sought the optimal solution. There are two methods to determine the optimal solution:

1. Method springboard (stepping stone)

2. Method Modified Distribution (MODI)

At the completion of the initial solution, the four methods of each function to determine the allocation of the initial distribution that will make the entire capacity resources allocated to all destinations. But this is only the beginning of a solution that does not need the optimum. The reality of the four methods for obtaining an initial solution, Vogell Approximation Method (VAM) will have an initial optimum solution as compared to the three other methods. VAM perform allocation in a way that will minimize the penalty(opportunitycost)in choosing the wrong box to a location, and also reduce a lot of iterations required to achieve the optimum solution. Unlike the North West Corner method does not consider the transportation costs per unit in making allocations. So take a few iterations additional solutions to obtain the optimum solution (siswanto., 2007)

Tintin moon in his research mentioned North West Corner has the advantage of faster decision-making and without being too complicated in the placement of units to be distributed to the request. In contrast to other methods such as for example the method of Least Cost to first consider in terms of cost, so that if there is a charge pendistribusiaan it will be longer in the decision (Tintin 2016: 13).

Therefore, the methods discussed in this study are Vogell Approximation Method (VAM) and methods of North West Corner. Namely to examine the effectiveness Vogell Approximation Method (VAM) to minimize transportation costs than the method of North-West Corner. VAM is a calculation that starts from the top left corner and then walk to the next cell in accordance algorithm available regardless of cost. This method is simpler to use, because it does not require a closed path (closed path). VAM is done by calculating the difference between the smallest cost to the next smallest cost for each column and row. Then select the site and allocate the excess cost of products as possible to the cell that has the smallest cost. This method is repeated until all the products have already been allocated. While the method of North-West Corner is a calculation that starts with an initial allocation menentuan cell values assigned to the cells that are in the top left corner of the table. The value of the initial cell depends on the constraints - the constraints of supply and demand for cell (Keliat, 2013: 74).

In a sense effectiveness is precisely the achievement of goals or selecting the appropriate objectives of a series of alternative or choice of ways and the choice of several other options. Effectiveness can also be interpreted as a measure of success in achieving the goals that have been determined. Thus, the effectiveness of the method of VAM is referred to in this study is the successful method of VAM to minimize transportation costs with measures that are determined, with indicators:

1. speed and precision of the workmanship obtained faster than methods NWC

2. differences result transport costs gained significantly 
As for the type of data used in this research is secondary data. Namely data obtained from agencies that are processed in the form of journals, books, literature, or other sources of information relating to the subject matter discussed in this study.

\section{Method:-}

This study is based on a literature review method, ie the theoretical description of the object under study in a way understand, observe and examine the existing knowledge in the literature (reading materials, reference books or other research) to support research. The study was conducted in the library of the State University of Medan.

The steps in this research are:

1. Collecting and studying libraries relating to research materials as a matrix, operations research, linear programming, and transport models.

2. Analysis and Troubleshooting:

1. Describes the basic matrix theory, operations research, linear programming, and transport models that support the discussion.

2. Taking the example of a transportation model.

Transportation problem under study is the distribution of a single product from multiple sources, with limited offerings, to multiple destinations with a specific request, with minimum transport costs. (Abdul., Et al ,. 2012)

3. Diagnosing the problem begins with the introduction of the source, destination, parameters and variable.

4. Then create a matrix of transport. In this case, When the whole resource capacity is greater than demand the whole purpose then a pseudo column(dummy)should be added to accommodate the excess capacity.

5. When the capacity of all sources is less than the entire demand of interest then a false line needs to be added to provide a pseudo-capacity that will meet the excess demand. Obviously that excess demand can not be met.

6. Finding the optimum solution the beginning of a case of transport model using the northwest corner and VAM.

7. Finding the optimum solution end with MODI.

8. Perform analysis to compare the results obtained.

9. Knowing the advantages of VAM

10. Make conclusions.

\section{Result:-}

UD. Berdikari Tani is one of the industrial companies engaged in fertilizer. The company has business activities that sell and distribute fertilizers to plants and consumers who need such products in their business operations.

UD. Berdikari Tani has several factories to produce fertilizer and several warehouses. Once production is carried out, then the production is stored to multiple warehouses owned by UD. Tani Berdikari.

Tabel 1:- The UD. Berdikari transportation costs

\begin{tabular}{|l|l|l|l|l|}
\hline From/to & Gowa & Jeneponto & Bantaeng & Bulukumba \\
\hline K & 125.000 & 220.000 & 310.000 & 310.000 \\
\hline M & 140.000 & 215.000 & 250.000 & 280.000 \\
\hline L & 150.000 & 230.000 & 275.000 & 315.000 \\
\hline
\end{tabular}

Tabel 2:- Transportation UD. Berdikari Tani Matrix

\begin{tabular}{|c|c|c|c|c|c|}
\hline From/to & Gowa & jeneponto & Bantaeng & Bulukumba & Persediaan \\
\hline $\mathrm{K}$ & 1.000 & 1760 & 2.160 & 2.480 & \multirow{2}{*}{1.488} \\
\hline & & & & & \\
\hline M & 1.120 & 1.720 & 2.000 & 2.240 & 853 \\
\hline & & & & & \multirow{2}{*}{507} \\
\hline $\mathrm{L}$ & 1.200 & 1.840 & 2.200 & 2.520 & \\
\hline Demand & 279 & 808 & 565 & 1.196 & 2.848 \\
\hline
\end{tabular}

Analysis Method Using VAM (Initial Solution). The solution initially is as follows: 
Tabel 3:- VAM Transportation UD. Tani Berdikar

\begin{tabular}{|c|c|c|c|c|c|c|}
\hline From/to & Gowa & Jeneponto & Bantaeng & Bulukumba & Stock & Difference \\
\hline \multirow[t]{2}{*}{$\mathrm{K}$} & 1000 & 1760 & 2160 & 2480 & \multirow[t]{2}{*}{1488} & \multirow[t]{2}{*}{ - } \\
\hline & 279 & 808 & 401 & $\mathrm{X}$ & & \\
\hline \multirow[t]{2}{*}{ M } & 1120 & 1720 & 2000 & 2240 & \multirow[t]{2}{*}{853} & \multirow[t]{2}{*}{-} \\
\hline & $\mathrm{X}$ & $\mathrm{X}$ & $\mathrm{X}$ & 853 & & \\
\hline \multirow[t]{2}{*}{$\mathrm{L}$} & 1200 & 1840 & 2200 & 2520 & \multirow[t]{2}{*}{507} & \multirow[t]{2}{*}{-} \\
\hline & $X$ & $\mathrm{X}$ & 164 & 343 & & \\
\hline Demand & 279 & 808 & 565 & 1196 & 2848 & - \\
\hline
\end{tabular}

Furthermore, this solution will be optimized by using MODI.

Tabel 4:- Final Solution

\begin{tabular}{|c|c|c|c|c|c|}
\hline From/to & $\begin{array}{l}\text { Gowa } \\
V=1000\end{array}$ & $\begin{array}{l}\text { Jeneponto } \\
\mathrm{V}=1760\end{array}$ & $\begin{array}{l}\text { Bantaeng } \\
V=2160\end{array}$ & $\begin{array}{l}\text { Bulukumba } \\
V=2480\end{array}$ & Stock \\
\hline $\begin{array}{l}\mathrm{K} \\
\mathrm{U}=0\end{array}$ & $\frac{1000}{279}$ & $\begin{array}{l}1760 \\
808\end{array}$ & $\begin{array}{l}2160 \\
401\end{array}$ & 2480 & 1488 \\
\hline $\begin{array}{l}\mathrm{M} \\
\mathrm{U}=240\end{array}$ & 1120 & 1720 & 2000 & $\begin{array}{l}2240 \\
853\end{array}$ & 853 \\
\hline $\mathrm{L}$ & $\begin{array}{l}1200 \\
X\end{array}$ & $\begin{array}{l}1840 \\
X \\
\end{array}$ & $\begin{array}{l}2200 \\
164 \\
\end{array}$ & $\begin{array}{l}2520 \\
343 \\
\end{array}$ & 507 \\
\hline Demand & 279 & 808 & 565 & 1196 & 2848 \\
\hline
\end{tabular}

From the table shows that using VAM as an initial solution and MODI as the ultimate solution provides total transportation costs USD 5.70312 million, -

Analysis by Using Method North - West Corner

Solutions originally was as follows:

Tabel 5:- Table solution Using West-Corner

\begin{tabular}{|c|c|c|c|c|c|}
\hline From/to & Gowa & Jenepor & Bantae & Buluku & Stock \\
\hline $\mathrm{K}$ & $\begin{array}{l}1000 \\
279 \\
\end{array}$ & 1760 & 2160 & 2480 & 1488 \\
\hline $\mathrm{M}$ & $\begin{array}{l}1120 \\
X\end{array}$ & 1720 & 2000 & 2240 & 853 \\
\hline $\mathrm{L}$ & $\begin{array}{l}1200 \\
X\end{array}$ & 1840 & 2200 & 2520 & 507 \\
\hline Demand & 279 & 808 & 565 & 1196 & 2848 \\
\hline
\end{tabular}

Furthermore, this solution will be optimized by using MODI

Tabel 6:- Optimal Solution UD.Berdikari Tani Using MODI

\begin{tabular}{|c|c|c|c|c|c|}
\hline From/to & $\begin{array}{l}\text { Gowa } \\
V=1000\end{array}$ & $\begin{array}{l}\text { Jeneponto } \\
\mathrm{V}=1760\end{array}$ & $\begin{array}{l}\text { Bantaeng } \\
V=2160\end{array}$ & $\begin{array}{l}\text { Bulukumba } \\
\mathrm{V}=2480\end{array}$ & Stock \\
\hline $\mathrm{K}$ & 1000 & 1760 & 2160 & 2480 & 1488 \\
\hline $\mathrm{U}=0$ & 279 & 808 & 401 & & \\
\hline $\mathrm{M}$ & 1120 & 1720 & 2000 & 2240 & 853 \\
\hline $\mathrm{U}=-240$ & & & & 853 & \\
\hline $\mathrm{L}$ & 1200 & 1840 & 2200 & 2520 & 507 \\
\hline $\mathrm{U}=40$ & $X$ & $X$ & 164 & 343 & \\
\hline Demand & 279 & 808 & 565 & 1196 & 2848 \\
\hline
\end{tabular}

From the table shows that by using the NWC as the initial solution and MODI as the ultimate solution provides total transportation costs USD 5.70312 million, - ,

Completion of the problem in determining the minimal cost of distribution by using VAM and NWC in Semen Bosowa South Region. As for the cost of transportation Bosowa in distributing products from each depot to every store parent is: 
Tabel 7:- Transportation costs Bosowa

\begin{tabular}{|l|l|l|l|l|l|}
\hline From/to & S & F & A & B & C \\
\hline J & 2500 & 2250 & 2000 & 2000 & 1500 \\
\hline B & 1250 & 1500 & 1750 & 1750 & 2500 \\
\hline
\end{tabular}

Furthermore, the following table illustrates the matrix table transport Semen Bosowa

Tabel 8:- Matrix Transportation costs Bosowa

\begin{tabular}{|c|c|c|c|c|c|c|}
\hline From/to & $\mathrm{S}$ & $\mathrm{F}$ & $\mathrm{A}$ & B & $\mathrm{C}$ & Suplai \\
\hline $\mathrm{J}$ & 2500 & 1760 & 2160 & 2480 & 1500 & 5000 \\
\hline B & 1250 & 1720 & 2000 & 2240 & 2500 & 12500 \\
\hline Dummy & 0 & 0 & 0 & 0 & 0 & 4000 \\
\hline Demand & 3000 & 10000 & 3000 & 5000 & 500 & 21500 \\
\hline
\end{tabular}

Furthermore, this solution will be optimized by using MODI

Tabel 9:- Optimal Solution VAM

\begin{tabular}{|c|c|c|c|c|c|c|}
\hline From/to & $\begin{array}{l}\mathrm{S} \\
\mathrm{V}=1750\end{array}$ & $\begin{array}{l}F \\
V=2000\end{array}$ & $\begin{array}{l}A \\
V=2000\end{array}$ & $\begin{array}{l}B \\
V=2000\end{array}$ & $\begin{array}{l}\mathrm{C} \\
\mathrm{V}=1500\end{array}$ & Suplai \\
\hline $\begin{array}{l}\mathrm{J} \\
\mathrm{U}=0\end{array}$ & 2500 & 1760 & 2160 & $\begin{array}{l}2480 \\
4500\end{array}$ & $\begin{array}{l}1500 \\
500\end{array}$ & 5000 \\
\hline B & $\begin{array}{l}1250 \\
3000\end{array}$ & $\begin{array}{l}1720 \\
9500\end{array}$ & 2000 & 2240 & 2500 & 12500 \\
\hline Dummy & 0 & $\begin{array}{l}0 \\
500\end{array}$ & $\begin{array}{l}0 \\
3000\end{array}$ & $\begin{array}{l}0 \\
500\end{array}$ & 0 & 4000 \\
\hline Demand & 3000 & 10000 & 3000 & 5000 & 500 & 21500 \\
\hline
\end{tabular}

From the table shows that using VAM as an initial solution and MODI as the ultimate solution provides total transportation cost Rp 27.75 million, -.

Tabel 10:- Optimal Solution NWC

\begin{tabular}{|c|c|c|c|c|c|c|}
\hline From/to & $\begin{array}{l}\mathrm{S} \\
\mathrm{V}=1750\end{array}$ & $\begin{array}{l}F \\
V=2000\end{array}$ & $\begin{array}{l}A \\
V=2000\end{array}$ & $\begin{array}{l}B \\
V=2000\end{array}$ & $\begin{array}{l}\mathrm{C} \\
\mathrm{V}=1500\end{array}$ & Suplai \\
\hline $\begin{array}{l}\mathrm{J} \\
\mathrm{U}=0\end{array}$ & $\begin{array}{l}2500 \\
1000\end{array}$ & $\begin{array}{l}1760 \\
4000\end{array}$ & 2160 & $\begin{array}{l}2480 \\
4500\end{array}$ & $\begin{array}{l}1500 \\
500\end{array}$ & 5000 \\
\hline B & $\begin{array}{l}1250 \\
2000\end{array}$ & $\begin{array}{l}1720 \\
6000\end{array}$ & $\begin{array}{l}2000 \\
3000\end{array}$ & $\begin{array}{l}2240 \\
1500\end{array}$ & 2500 & 12500 \\
\hline Dummy & 0 & 0 & 0 & $\begin{array}{l}0 \\
3500 \\
\end{array}$ & \begin{tabular}{|c|}
0 \\
500
\end{tabular} & 4000 \\
\hline Demand & 3000 & 10000 & 3000 & 5000 & 500 & 21500 \\
\hline
\end{tabular}

From the table shows that by using the NWC as the initial solution and MODI as the ultimate solution provides total transportation costs Rp.30.875.000, -.

Discussion:-

MODI method employed in this paper can be used with good deal of success in solving such problems. This is because while working hand in hand with the remaining three methods, MODI method computed the optimal solution within a shorter period of time (Rekha vivek joshi., 2013).

The main aim of this paper is to achieve the optimal transportation cost by using the new method with the required number of steps and it's very easy to understand. Based on the optimal solution it allows us to taking a decision effectively. Thus, there are possible extensions to improve our algorithm of the method. The decision maker goes through all the steps of algorithm which makes our approach very useful to be applied in a lot of real world problems (Reena G. Patel et all., 2017) 
hus it can be concluded that ASM-Method provides an optimal solution directly, in fewer iterations, for the transportation problems. As this method consumes less time and is very easy to understand and apply, so it will be very helpful for decision makers who are dealing with logistic and supply chain problems (Abdul Quddoos., Et al., 2012).

\section{Conclusions:-}

Based on the results obtained, the conclusion to be drawn is:

1. In the case of UD. Tani Berdikari, speed and precision of the workmanship with VAM methods obtained more quickly, because the current execution optimum solution obtained from the initial solution methods NWC found negative index numbers should be obtained phase / additional iterations to obtain the optimal distribution costs.

2. In the case of the distribution of Semen Bosowa South Region VAM also proved effective in minimizing the transportation costs of distribution with unbalanced transportation problem that the number of deals (Supply) is less than the total demand (Demand) with a significant proportion of transport costs.

3. The advantages compared to methods NWC method VAM

VAM method easier and faster to regulate the allocation (in this case is the cost of transportation) from some source to the destination while the NWC method does not allocate many products as possible on cell boxes that have the smallest transport costs. In other words, any product allocation no regard to the cost per unit. This method is only allocating products based on criteria of the upper left corner and lower right corner is the base cell. Therefore, do not pay attention to the cost per unit, NWC method is less efficient.

\section{Acknowledgments:-}

This is a thesis research, thanks to supervisors and related parties who have been concerned to provide input for the development of this research.

\section{References:-}

1. Abdul Quddoos., Et al 2012. A New Method for finding an optimal solution for transportation problems. International Journal on Computer Science and Engineering (IJCSE),4.1271 to 1274

2. Anton, H and Chris R, 2004.Aplikasi Linear Aljabar Eight Edition. Jakarta

3. Chandra, Tintin, 2016: Implementation of Algorithms North West Corner In Troubleshooting Transport. Times, 5, 12-16.

4. Hillier, F and Gerald Lieberman, 1990: Introduction to Operations Research Fifth Edition. Jakarta

5. Gauran, Sharma, SH Abbas, Vijay Kumar Gupta, 2015. Solving time minimizing transportation problem by zero-point method. International Journal of Engineering and Science, 5, 23-26.

6. Mujahidah, et al, 2015 Synergetic Teaching Strategies To Improve Student Reading Skills Semester Three Stain Pare Pare, curiosity Edition VIII, 2, 1-18.

7. Mulyono, Sri, 2002, Operations Research. Jakarta.

8. Murthy, P Rama, 2007, Operation Research, Second Edition. New Delhi: New Age International (P) Limited, Publishers.

9. Nikolic., Ilija, 2007. Total time minimizing transportation problem. Yogoslav Journal of Operations Research, 1, 125-133.

10. Reena Patel G., Bhatwala PH 2013. The advance method for the optimum solution of a transportation problem. International Journal of science and research (IJSR). 4. 2319-7064.

11. Reena Patel G et all, 2017. On Optimal Solution of a Transportation Problem. Global Journal of Pure and Applied Mathematics. Vol.13. 6201-6208

12. Rekha Vivek Joshi., 2013. Optimization techniques for transportation problems of three variables. IOSR Journal of matematics (IOSR-JM), 9, 2278-5728.

13. Singh, S. GC Dubey. Rajesh Shrivastava. 2012: A Various to Solve the Optimality for the Transportation Problem, International Journal of Mathematical Science Engineeringang Vol 1: 21-28.

14. Siswanto, 2007: Operation Research Volume 1. Jakarta

15. Supranto, Johannes. 2013: Operations Research for Decision Making Third Edition. Jakarta

16. Thie PGEK, 2008, An Introduction to Linear Programming and game theory, John Wiley and Sons, Inc., Canada.

17. Zulfikarizah, F, 2004: Operation Research, Malang. 